\title{
Skill Level and the Returns to Job-Tenure in Internal Labour Markets in Australia
}

\author{
Michael Dobbie \\ Department of Economics, Macquarie University \\ Balaclava Road, North Ryde NSW 2109, Sydney, Australia \\ Tel: 61-2-9850-8502 E-mail: michael.dobbie@mq.edu.au
}

Craig MacMillan

Department of Economics, Macquarie University

Balaclava Road, North Ryde NSW 2109, Sydney, Australia

Tel: 61-2-9850-7290Ｅ-mail: craig.macmillan@mq.edu.au

$\begin{array}{lr}\text { Received: May 16, } 2011 & \text { Accepted: June 15, } 2011 \quad \text { Published: October 1, } 2011 \\ \text { doi:10.5539/ass.v7n10p3 } & \text { URL: http://dx.doi.org/10.5539/ass.v7n10p3 }\end{array}$

\begin{abstract}
Both the enterprise and salaried versions of the internal labour market model predict an important role for job specific tenure in the determination of employee earnings. This paper estimates earnings equations using data drawn from the 2005 wave of the Survey of Education and Training Experience (hereafter SETE) to test this idea. The paper finds considerable support for the presence of a job tenure effect, even after controlling for general labour market experience. The paper also seeks to determine if the strength of the tenure effect is related to skill level. The paper finds that the evidence for a tenure effect is strong across the broad spectrum of skill levels, except for the least skilled workers, where the job tenure earnings profile is noticeably flatter. This in turn suggests that internal labour markets have broad relevance across the whole of the skill spectrum, but with somewhat less importance for the least skilled workers.
\end{abstract}

Keywords: Internal labour markets, Job-tenure, Labour market experience, Occupation, Skill

\section{Introduction}

The concept of an internal labour market (ILM) was introduced by Clark Kerr (1950 and 1954) and John Dunlop (1957 and 1966) in the 1950s and 1960s. The concept was further developed by a number of institutionalist labour economists in the US during the 1970s and 1980s, in particular Peter Doeringer, Michael Piore and Paul Osterman (Doeringer and Piore, 1971; Osterman, 1984, 1987 and 1994; Osterman and Burton, 2005; Piore, 2002). In addition, a number of economists working in the more mainstream fields of new institutional economics (Baker et al, 1994a and b; Wachter and Wright, 1990; Williamson et al, 1975) and personnel economics (Lazear, 1992; Lazear and Oyer, 2004) have made important contributions to the study of ILMs.

Arguably, Doeringer and Piore (1971[1985]) provided the classic definition of an ILM:

The basic assertion ... is that there is an institutional structure to labor markets reflected in a sharp distinction between internal and external market arrangements. The internal labor market is defined by an enterprise, or a part of an enterprise, or by a craft or professional community (p. $x$ ).

Doeringer and Piore (1971) discussed two types of ILMs, enterprise and craft but focussed on the former. Enterprise ILMs were characterised by well defined job ladders, limited ports of entry towards the bottom of job ladders, promotion from within, seniority-based employment security rules, production processes that were heavily reliant on firm-specific skills, wages that were attached to jobs rather than individuals and a wage structure primarily determined by administrative rules linked to the logic of the internal job structure. Consequently, in enterprise ILMs job tenure tends to be lengthy, training is extensive, wages are positively related to job tenure and significantly insulated from external market forces. Doeringer and Piore argued that 
these ideal-typical features of enterprise ILMs were most relevant to US blue-collar manufacturing workplaces although they also argued that many features were present in white-collar and managerial labour markets.

Osterman (1984 and 1987) identified another ILM, called the salaried model that was a better description of the institutional rules governing the allocation of white-collar and managerial labour within firms. The key features of the salaried model included, greater flexibility in the allocation of work, an implicit guarantee of lifetime employment based on work reassignment rather than lay-offs, less well defined job ladders and promotion sequences and wages that were more linked to individuals than to jobs with a greater role for merit considerations. As with the enterprise model, the salaried model was associated with lengthy job tenure, significant expenditure on training to facilitate worker reassignment, and wages that reflected a significant role for firm tenure.

This paper examines one key feature of both the enterprise and salaried ILMs. In both models, job tenure plays an important role in the determination of the wages of employees. This paper tests for such an effect by estimating a cross-section earnings equation using data from 2005. The literature on blue-collar and white-collar ILMs points to the fact that the importance of ILMs may vary with the skill level of the workers involved. With this in mind the paper also aims to determine if the importance of job tenure is related to skill level.

It is acknowledged that the literature presents more than one way to interpret the relationship between job tenure and earnings. Indeed an interesting strand of this literature questions whether there is a relationship between job tenure and earnings at all. It is beyond the scope of this paper however to sort these issues out. In this paper we proceed on the assumption that any returns to job tenure are indeed returns to the accumulation of job specific human capital occurring within the ILM. See Topel (1991) and Manning (1998) for interesting discussions of these issues.

The paper is structured as follows. Section 2 discusses data and methodology, in Section 3 the results of the empirical investigation are presented and discussed. The results show that there is a tenure effect, but that it is the least pronounced for the least skilled workers. Section 4 of the paper provides some concluding comments.

\section{Data and Methodology}

\subsection{Data}

The Australian Bureau of Statistics (ABS) has conducted the SETE every four years since 1989. The data collected provide researchers with the opportunity to examine job tenure and general labour market experience for a large sample of workers. The present research draws on a sub-set of the SETE data pertaining to wage and salary earners because this is the most relevant group of workers to examine when considering questions relating to ILMs. In other words, owner managers of incorporated and unincorporated enterprises are excluded from the analysis undertaken here and this is consistent with overseas studies of job tenure. In addition, casual employees are excluded from the analysis since by definition they tend not to be covered by ILMs. This paper uses data from the 2005 wave of the survey.

\subsection{Methodology}

The empirical analysis in relation to earnings is conducted by estimating a cross-section earnings equation. The equation estimated has the following form:

$$
\ln W_{i}=\beta_{0}+X_{i} \beta_{1}+\operatorname{Exp}_{i} \beta_{2}+\operatorname{Ten}_{i} \beta_{3}+\varepsilon_{i}
$$

$i=1, \ldots \ldots, N$

Where

$\ln W_{i}=$ the log hourly wage of employee $i$.

$X_{i}=$ a vector of standard control variables including the following. Gender, education, whether the employee is from a non-English speaking background, whether the employee is a union member, occupation, industry, region, firm size, public versus private sector, marital status, whether the employee has dependent children under the age of twelve, whether any work-related training courses were undertaken in previous 12 months, time spent on work related training courses undertaken in previous 12 months.

$\operatorname{Exp}_{i}=$ potential experience of employee $i$ measured in years.

$\mathrm{Ten}_{i}=$ job tenure of employee $i$ measured in years.

$\varepsilon_{i}=$ a random disturbance term. 
Appendix 1 contains a full description of each variable entering (1). Appendix 2 has the mean and standard deviation of each variable entering (1).

\section{Key variables defined}

The variables that are of interest to the research in this paper are potential experience and job tenure variables. For the sake of brevity, only these variables are discussed in detail.

Experience: This is the usual potential experience variable. It is defined as Age - (Years in school + 5). The interpretation of the coefficient attached to this variable is that it captures the average return to an additional year of general training that accumulates with experience (Topel, 1991). This general training is by definition portable between firms. It is equally valuable across all firms who hire this type of labour. A quadratic of experience is also entered into the empirical model to capture the possibility of a non-linear relationship between earnings and experience.

Job Tenure: This variable measures tenure in each worker's current job. The coefficient attached to this variable is usually interpreted as capturing the average return to an additional year of job-specific training. This would be lost if the job were to end (Topel, 1991). A quadratic of job tenure is also entered into the empirical model to capture the possibility of a non-linear relationship between earnings and job tenure. The estimates for this coefficient will allow us to test some key ideas. If ILMs are not important, we should expect to find little or no role for the job tenure variable in the formation of earnings $\left(\beta_{3}=0\right)$. A significant role for job tenure on the other hand $\left(\beta_{3}>0\right)$, is taken to be evidence in favour of ILMs.

\section{Estimation of the model by skill level}

The cross-section earnings equation is estimated separately for each skill grouping in the Australian Standard Classification of Occupations, (hereafter ASCO). Table 1 summarises the main occupational groups and skill levels in ASCO. ASCO is a skill based occupational classification system that embraces all occupations in the Australian workforce. In ASCO skill level is measured by the formal education and or training required to enter an occupation as well as previous experience usually required to enter an occupation. For example in ASCO I, the highest skill level, most occupations require a skill level commensurate with a Bachelors degree or higher, or at least five years of relevant experience. In some cases relevant experience is required in addition to the formal qualifications. ASCO I embraces managers and administrators and professionals. At the other end of the skill spectrum, ASCO V consists of occupations with a skill level commensurate with completion of compulsory secondary school or an Australian Qualifications Framework (hereafter AQF) Certificate 1 qualification. ASCO $\mathrm{V}$ embraces labourers and related workers, as well as elementary clerical sales and service workers. The earnings equation is estimated separately for each ASCO category. This will allow us to gain some insight into whether the tenure effect operates in the same way across these skill categories.

\section{Results}

Table 2 reports the key results from earnings equations estimated for each ASCO group. In order to facilitate the discussion, Table 2 does not report all the regression output associated with each earnings equation. Rather, it shows the coefficient estimates that are of direct relevance to the focus of this paper. As noted above these are the experience and job tenure variables. A full set of results is available from the authors on request. Table 3 uses the estimated coefficients from Table 2 to calculate the marginal effect of an additional year of either experience or tenure, evaluated at ten years.

The picture that emerges from Tables 2 and 3 is as follows. General labour market experience dominates job tenure in both a numerical and statistical sense. This is evident from Table 2 in the fact that the coefficient estimates for the experience variable tend to be twice the size of those for the tenure variable. Moreover the t-statistics associated with the coefficient estimates for experience are usually much larger than the corresponding t-statistics on the estimated coefficients of the tenure variable. Table 3 shows the effect of an additional year of either experience or tenure, evaluated at ten years. It can be seen that the return to an additional year of experience is always greater than for an additional year of tenure, and ranges from 0.9 to 2.6 percentage points.

The estimates indicate that job tenure, while not as important as general experience, nevertheless has a statistically significant effect on earnings. This true for all ASCO groups, as can be seen from Table 2. From Table 3 it can be seen that the return to an extra year of tenure ranges from 0.5 to 0.9 percent. This suggests that ILMs are a feature in wage determination for all occupational skill groups. One qualification to this relates to the results for ASCO V, the least skilled category. This group, as noted above, comprises 'Labourers and related workers' and 'Elementary clerical, sales and service workers'. Table 2 indicates that for this group the job tenure 
variable is just significant at the ten per cent significance level, whereas in all other cases this variable is significant at the one per cent significance level. In addition the magnitude of the effect of job tenure on earnings is about half as important for ASCO V as in the case of the other groups (see Table 3).

We interpret the flatter job tenure earnings profile for ASCO V as a sign that firms place a lower value on job tenure for these occupational groups. This implies that the skills required by the occupations in ASCO V can be more easily obtained by firms in the external labour market, than is the case for the other ASCO categories. If this is so then they have less incentive to develop ILMs for this kind of worker. So while the evidence suggests that ILMs are present across the broad range of skill categories, they are likely to be of relatively less importance for the lowest skilled workers.

One limitation of this study relates to the use of cross-sectional data. This type of data does not allow us to control for well known potential endogeneity problems. Future research will focus on the use of panel data in order to better address these issues.

\section{Conclusion}

This paper has estimated a cross-section earnings equation which includes job tenure as a regressor. The results indicate that for all ASCO categories, the job tenure earnings profiles slope up. Indeed the profiles are similar for all occupational groups except the least skilled. For the latter the profile is noticeably flatter. This suggests that job tenure is less important in these occupations. From an ILM perspective this suggests that firms have less incentive to develop ILMs for these types of workers. Overall however, the evidence is that job tenure is important across the broad range of skill levels. The evidence presented in this paper suggests that the ILM is a potentially important explanatory model for wages of both high and low skilled workers.

\section{References}

ABS (Australian Bureau of Statistics). (1997). Australian Standard Classification of Occupations, Second Edition, 1997, ABS Cat No. 1220.0. Canberra.

ABS (Australian Bureau of Statistics). (2005). Survey of Education and Training Experience. Cat. No. 6278.0. Canberra.

Baker, G., Gibbs, M. and Holmstrom, B. (1994a). The Internal Economics of the Firm: Evidence from Personnel Data. Quarterly Journal of Economics, 109(4): 881-919. http://dx.doi.org/10.2307/2118351

Baker, G., Gibbs, M. and Holstrom, B. (1994b). The Wage Policy of a Firm. Quarterly Journal of Economics 109(4): 921-955. http://dx.doi.org/10.2307/2118352

Doeringer, P. B., and Piore, M. J. (1971[1985]). Internal Labor Markets and Manpower Analysis. Lexington: D. C. Heath 1971; Armonk: M. E. Sharpe, 1985.

Dunlop, J. T. (1957). The Task of Contemporary Wage Theory, in G. W. Taylor and F. C. Pierson (eds) New Concepts in Wage Determination. New York: McGraw-Hill.

Dunlop, J. T. (1966). Job Vacancy Measures and Economic Analysis, in NBER, The Measurement and Interpretation of Job Vacancies: A Conference Report. New York: Columbia University Press.

Kerr, C. (1950). Labor Markets: Their Character and Consequences, Proceedings of the Second Annual Meeting, Industrial Relations Research Association. Reprinted in Kerr, C. (1977) Labor Markets and Wage Determination: The Balkanization of Labor Markets and Other Essays. Los Angeles: University of California Press.

Kerr, C. (1954). The Balkanization of Labor Markets, in E. Wright Bakke (ed) Labor Mobility and Economic Opportunity, Cambridge MA: MIT Press. Reprinted in Kerr, C. (1977) Labor Markets and Wage Determination: The Balkanization of Labor Markets and Other Essays, Los Angeles: University of California Press.

Lazear, E. P. (1992). The Job as a Concept, in W. J. Bruns (ed) Performance Measurement, Evaluation and Incentives. Boston MA: Harvard Business School Press.

Lazear, E. P. and Oyer, P. (2004). Internal and External Labor Markets: A Personnel Economics Approach. Labour Economics, 11: 527-554. http://dx.doi.org/10:1016/j.labeco.2004.01.001

Manning, A. (1998). Mighty Good Thing: The Returns to Tenure. Centre for Economic Performance, Discussion Paper No. 383, London School of Economics.

Osterman, P. (1984). White-Collar Internal Labor Markets, in P. Osterman (ed) Internal Labor Markets. Cambridge, MA: MIT Press. 
Osterman, P. (1987). Choice of Employment Systems in Internal Labour Markets. Industrial Relations 26(1): 46-67. http://dx.doi.org/10.1111/j.1468-232X.1987.tb00693.x

Osterman, P. (1994). Internal Labour Markets: Theory and Change, in C. Kerr and P.D. Staudohar (eds) Labor Economics and Industrial Relations: Markets and Institutions. Cambridge, MA: Harvard University Press.

Osterman, P. and Burton, M. D. (2005). Ports and Ladders: The Nature and Relevance of Internal Labour markets in a Changing World, in S. Ackroyd, R. Batt, P. Thompson and P. S. Tolbert (eds) The Oxford Handbook of Work and Organization. Oxford: Oxford University Press.

Piore, M. J. (2002). Thirty Years Later: Internal Labor Markets, Flexibility and the New Economy. Journal of Management and Governance, 6: 271-279. http://dx.doi.org/10.1023/A:1021212904674

Topel, R. (1991). Specific Capital, Mobility, and Wages: Wages Rise with Job Seniority. Journal of Political Economy, 99: 145-176. http://dx.doi.org/10.1086/261744

Wachter, M. and Wright, R. (1990). The Economics of Internal Labor Markets. Industrial Relations, 29(2): 240-262. http://dx.doi.org/10.1111/j.1468-232X.1990.tb00753.x

Williamson, O., Wachter, M. and Harris, J. (1975). Understanding the Employment Relation: The Analysis of Idiosyncratic Exchange. Bell Journal of Economics, 6: 250-280. http://dx.doi.org/10.2307/3003224

Table 1. The Australian Standard Classification of Occupations

\begin{tabular}{|c|c|c|c|}
\hline $\begin{array}{l}\text { Major } \\
\text { Groups }\end{array}$ & Occupations & Skill Level & $\begin{array}{l}\text { Description of skill } \\
\text { level required for entry } \\
\text { into this occupation \# }\end{array}$ \\
\hline 1 & Managers and Administrators & ASCO I & $\begin{array}{l}\text { Bachelor degree or } \\
\text { higher or at least five } \\
\text { years } \\
\text { experience }\end{array}$ \\
\hline 2 & Professionals & ASCO I & \\
\hline 3 & Associate Professionals & ASCO II & AQF Diploma \\
\hline & & & $\begin{array}{l}\text { Advanced Diploma or at } \\
\text { least } 3 \text { years relevant } \\
\text { experience }\end{array}$ \\
\hline 4 & Tradespersons and Related Workers & ASCO III & $\begin{array}{l}\text { AQF Certificate III or } \\
\text { IV or at least three years } \\
\text { relevant experience }\end{array}$ \\
\hline 5 & Advanced Clerical and Service Workers & ASCO III & \\
\hline 6 & Intermediate Clerical, Sales and Service Workers & ASCO IV & $\begin{array}{l}\text { AQF Certificate II or at } \\
\text { least one year relevant } \\
\text { experience }\end{array}$ \\
\hline 7 & Intermediate Production and Transport Workers & ASCO IV & \\
\hline 8 & Elementary Clerical, Sales and Service Workers & ASCO V & $\begin{array}{lr}\text { Completion } & \text { of } \\
\text { compulsory } & \text { secondary }\end{array}$ \\
\hline & & & $\begin{array}{l}\text { school or } \\
\text { Certificate I }\end{array}$ \\
\hline
\end{tabular}

Source: ABS, Australian Standard Classification of Occupations, Second Edition, 1997, ABS Cat No. 1220.0. \# note that this is a simplified description. For more detail consult ABS Cat No. 1220.0. 
Table 2. Earnings Equations Persons 2005: Dependent Variable is Log-Hourly Wages

\begin{tabular}{|c|c|c|c|c|c|}
\hline & ASCO I & ASCO II & ASCO III & ASCO IV & ASCO V \\
\hline Experience & $\begin{array}{l}.021 * * \\
(7.46)\end{array}$ & $\begin{array}{l}.013^{* *} \\
(3.73)\end{array}$ & $\begin{array}{l}.038 * * \\
(13.66)\end{array}$ & $\begin{array}{l}.019^{* *} \\
(10.21)\end{array}$ & $\begin{array}{l}.022 * * \\
(7.96)\end{array}$ \\
\hline $\begin{array}{l}\text { Experience } \\
\text { squared }\end{array}$ & $\begin{array}{c}-.0003 * * \\
(-5.93)\end{array}$ & $\begin{array}{c}-.0002 * * \\
(-2.88)\end{array}$ & $\begin{array}{c}-.0006^{* *} \\
(-11.48)\end{array}$ & $\begin{array}{c}-.0003 * * \\
(-8.53)\end{array}$ & $\begin{array}{c}-.0004 * * \\
(-7.35)\end{array}$ \\
\hline Job tenure & $\begin{array}{l}.013 * * \\
(5.37)\end{array}$ & $\begin{array}{l}.01 * * \\
(2.95)\end{array}$ & $\begin{array}{l}.015^{* *} \\
(5.03)\end{array}$ & $\begin{array}{l}.012 * * \\
(5.76)\end{array}$ & $\begin{array}{l}.007 \# \\
(1.94)\end{array}$ \\
\hline $\begin{array}{l}\text { Job tenure } \\
\text { squared }\end{array}$ & $\begin{array}{c}-.0003 * * \\
(-3.95)\end{array}$ & $\begin{array}{l}-.0001 \\
(-1.53)\end{array}$ & $\begin{array}{c}-.0003 * * \\
(-3.21)\end{array}$ & $\begin{array}{c}-.0002^{* *} \\
(-3.68)\end{array}$ & $\begin{array}{l}-.0001 \\
(-1.39)\end{array}$ \\
\hline Adj. R squared & 0.18 & 0.32 & 0.54 & 0.33 & 0.27 \\
\hline F stat & $17.12 * *$ & $16.03 * *$ & $42.28 * *$ & $33.04 * *$ & $11.98^{*}$ \\
\hline No. OBS & 2891 & 1235 & 1409 & 2579 & 1197 \\
\hline
\end{tabular}

Notes: **, * and \# imply significance at $1 \%, 5 \%$ and $10 \%$ respectively. The figures in brackets are $t$ ratios.

Table 3. Returns to experience and job tenure (\%)

\begin{tabular}{lccccc}
\hline & ASCO I & ASCO II & ASCO III & ASCO IV & ASCO V \\
\hline Job Tenure & 0.7 & 0.8 & 0.9 & 0.8 & 0.5 \\
Experience & 1.5 & 0.9 & 2.6 & 1.3 & 1.4
\end{tabular}

Notes: This table reports the percentage return to an extra year of experience, firm tenure or occupational tenure respectively. The returns are evaluated at 10 years. The returns are calculated using the coefficient estimates reported in Table 2. 
Appendix 1. Variable names and definition

LEARN2005 = Dependant variable; log-hourly earnings

EXPER $=$ Age $-($ years of schooling +5$)$

TENUREC $=$ years of tenure with current firm

TRAIN $=$ a dummy variable equal to 1 if some training undertaken in previous 12 months, zero otherwise

TRAINTIME $=$ time spent on all training courses undertaken in previous 12 months, in hours

CHILD = dummy equal to 1 if has dependent child under 12 years of age, zero otherwise

MARSTAT $=$ a dummy variable equal to 1 if married and zero otherwise

$\mathrm{BNESC}=$ a dummy variable equal to 1 if born in a non-English speaking country, zero otherwise

MALE $=$ a dummy equal to 1 if male, zero otherwise

$\mathrm{UNION}=$ a dummy equal to 1 if a union member, zero otherwise

PUBLIC $=$ a dummy equal to 1 if employed in the public sector, zero otherwise

MANAGER = dummy variable equal to 1 if ASCO occupation is 'Managers and administrators', zero otherwise

$\mathrm{PROF}=$ dummy variable equal to 1 if ASCO occupation is 'Professionals', zero otherwise

$\mathrm{APROF}=$ dummy variable equal to 1 if ASCO occupation is 'Associate professionals', zero otherwise

$\mathrm{TRAD}=$ dummy variable equal to 1 if ASCO occupation is 'Tradespersons and related workers', zero otherwise

ADVCLER = dummy variable equal to 1 if ASCO occupation is 'Advanced clerical and service workers', zero otherwise

INTCLER = dummy variable equal to 1 if ASCO occupation is 'Intermediate clerical, sales and service workers', zero otherwise

INTPRODT = dummy variable equal to 1 if ASCO occupation is 'Intermediate production and transport and workers', zero otherwise

ELCLER = dummy variable equal to 1 if ASCO occupation is 'Elementary clerical, sales and service workers', zero otherwise

$\mathrm{LAB}=$ dummy variable equal to 1 if ASCO occupation is 'Labourers and related workers', zero otherwise

TERT $=$ dummy variable equal to 1 if highest educational level is a bachelors degree, postgraduate degree, graduate diploma or graduate certificate, zero otherwise

ADVDIP = dummy variable equal to 1 if highest educational level is a diploma or advanced diploma, zero otherwise

ADVCERT = dummy variable equal to 1 if highest educational level is certificate III or IV, zero otherwise

BASCERT $=$ dummy equal to 1 if highest educational level is certificate I or II, zero otherwise

YEAR12 = dummy variable equal to 1 if year 12 is highest educational level, zero otherwise

$\mathrm{EARL}=$ dummy variable equal to 1 if left school prior to year 12, zero otherwise

SMALL = dummy variable equal to 1 if 19 or fewer employees at workplace, zero otherwise

LARGE $=$ dummy variable equal to 1 if 100 or more employees at workplace, zero otherwise

MEDIUM = dummy equal to 1 if 20 to 99 employees at workplace, zero otherwise

Industry Dummies $=$ one digit ANZSIC

Regional Dummies $=$ state and territory 
Appendix 2. Means and Standard Deviations

\begin{tabular}{|c|c|c|c|c|c|c|c|c|c|c|}
\hline & \multicolumn{2}{|c|}{ ASCO I } & \multicolumn{2}{|c|}{ ASCO II } & \multicolumn{2}{|c|}{ ASCO III } & \multicolumn{2}{|c|}{ ASCO IV } & \multicolumn{2}{|c|}{ ASCO V } \\
\hline LEARN2005 & 3.25 & $(.351)$ & 3.08 & $(.3431)$ & 2.91 & $(.4099)$ & 2.91 & $(.3212)$ & 2.77 & $(.3537)$ \\
\hline TRAIN & 0.75 & $(.4326)$ & 0.67 & $(.4700)$ & 0.50 & $(.5001)$ & 0.56 & $(.4957)$ & 0.41 & $(.4924)$ \\
\hline TRAINTIME & 26.44 & $(57.27)$ & 26.40 & $(57.95)$ & 20.86 & $77.15)$ & 16.67 & $(39.99)$ & 10.17 & $(39.51)$ \\
\hline CHILD & 0.37 & $(.4835)$ & 0.31 & $(.4665)$ & 0.28 & $(.4532)$ & 0.31 & $(.4634)$ & 0.25 & $(.4339)$ \\
\hline MARSTAT & 0.74 & $(.4360)$ & 0.69 & $(.4589)$ & 0.62 & $(.4845)$ & 0.68 & $(.4641)$ & 0.57 & $(.4941)$ \\
\hline BNESC & 0.13 & $(.3431)$ & 0.10 & $(.3029)$ & 0.01 & $(.1271)$ & 0.12 & $(.3295)$ & 0.15 & $(.3633)$ \\
\hline MALE & 0.49 & $(.5000)$ & 0.55 & $(.4970)$ & 0.71 & $(.4498)$ & 0.45 & $(.4984)$ & 0.48 & $(.5000)$ \\
\hline UNION & 0.32 & $(.4678)$ & 0.27 & $(.4458)$ & 0.27 & $(.4442)$ & 0.31 & $(.4639)$ & 0.35 & $(.4782)$ \\
\hline PUBLIC & 0.42 & $(.4940)$ & 0.31 & $(.4662)$ & 0.13 & $(.3425)$ & 0.24 & $(.4282)$ & 0.12 & $(.3324)$ \\
\hline MEDIUM & 0.32 & $(.4695)$ & 0.29 & $(.4549)$ & 0.27 & $(.4475)$ & 0.31 & $(.4640)$ & 0.31 & $(.4639)$ \\
\hline LARGE & 0.43 & $(.4962)$ & 0.33 & $(.4704)$ & 0.27 & $(.4485)$ & 0.35 & $(.4783)$ & 0.32 & $(.4681)$ \\
\hline SMALL & 0.25 & $(.4848)$ & 0.38 & $(.4597)$ & 0.46 & $(.4545)$ & 0.44 & $(.4456)$ & 0.47 & $(.4454)$ \\
\hline TERT & 0.65 & $(.4747)$ & 0.23 & $(.4214)$ & 0.04 & $(.2152)$ & 0.09 & $(.2897)$ & 0.04 & $(.2173)$ \\
\hline ADVDIP & 0.11 & $(.3248)$ & 0.16 & $(.3755)$ & 0.06 & $(.2479)$ & 0.08 & $(.2841)$ & 0.05 & $(.2277)$ \\
\hline ADVCERT & 0.07 & $(.2620)$ & 0.23 & $(.4214)$ & 0.40 & $(.4919)$ & 0.19 & $(.3997)$ & 0.14 & $(.3532)$ \\
\hline BASCERT & 0.003 & $(.0622)$ & 0.005 & $(.0764)$ & 0.01 & $(.1271)$ & 0.01 & $(.1284)$ & 0.01 & $(.1349)$ \\
\hline YEAR12 & 0.07 & $(.2677)$ & 0.19 & $(.3938)$ & 0.18 & $(.3849)$ & 0.21 & $(.4083)$ & 0.23 & $(.4232)$ \\
\hline EARL & 0.10 & $(.3987)$ & 0.18 & $(.3879)$ & 0.31 & $(.3443)$ & 0.42 & $(.4308)$ & 0.53 & $(.4356)$ \\
\hline MANAGER & 0.25 & $(.4345)$ & & & & & & & & \\
\hline PROF & 0.75 & $(.4345)$ & & & & & & & & \\
\hline \multicolumn{11}{|l|}{ APROF } \\
\hline TRAD & & & & & 0.76 & $(.426)$ & & & & \\
\hline ADVCLER & & & & & 0.24 & $(.426)$ & & & & \\
\hline INTCLER & & & & & & & 0.70 & $(.4571)$ & & \\
\hline INTPRODT & & & & & & & 0.29 & $(.4571)$ & & \\
\hline ELCLER & & & & & & & & & 0.52 & $(.4997)$ \\
\hline LAB & & & & & & & & & 0.47 & $(.4997)$ \\
\hline EXP & 25.65 & $(10.82)$ & 24.82 & $(11.45)$ & 21.20 & $(12.99)$ & 25.25 & $(12.37)$ & 23.61 & $(13.71)$ \\
\hline TENUREC & 8.73 & $(8.92)$ & 8.72 & $(9.21)$ & 7.05 & $(8.11)$ & 7.50 & $(8.19)$ & 6.89 & $(7.82)$ \\
\hline
\end{tabular}

Note: Standard deviations are in parenthesis. 